J. Clin. Chem. Clin. Biochem.

Vol. 23, 1985, pp. 69-76

\title{
Short-Term and Long-Term Intra-Individual Variations and Critical Differences of Haematological Laboratory Parameters
}

\author{
By G. M. P. J. Costongs, P. C.W. Janson, B. M. Bas
}

Hospital "De Goddelijke Voorzienigheid", Sittard, The Netherlands

\section{J. Hermans}

Department of Statistics, University of Leiden, Leiden, The Netherlands

\section{P. J. Brombacher and J. W. J. van Wersch}

De Wever Hospital, Heerlen, The Netherlands

(Received March 21/September 10, 1984))

Summary: The complete blood cell count and the differential leukocyte count have been studied for their variations within-one-day and during one week (short-term variations) and during a period of six months (long-term variations) with an automatic haematology analyser (H-6000, Technicon $\left.{ }^{\circledR}\right)$, in which some new parameters (large unstained cells, high peroxidase cells, red cell distribution width, platelet distribution width, mean platelet volume, plateletcrit) are included. The influence of external factors such as sex-differences, smoking/non-smoking, use of oral contraceptives etc. have also been studied. It appears that the use of critical differences together with haematological data improves the value of these parameters in diagnosis and treatment of patients.

Kur:- und langzeitige intra-individuelle Änderungen sowie kritische Differenzen hämatologischer Laboratoriumskenngrößen.

Zusammenfassung: Das Blutbild und das Differentialblutbild wurden hinsichtlich ihrer Änderungen innerhalb eines Tages, während einer Woche (Kurzzeit-Varianzen) und einer Periode von sechs Monaten (LangzeitVarianzen) mit einem automatischen Haematologie-Analysengerät $\left(\mathrm{H}-6000\right.$, Technicon $\left.{ }^{\circledR}\right)$ untersucht. Das Spektrum des Geräts wurde um einige neue Kenngrößen erweitert: Große ungefärbte Zellen, Peroxidase-reiche Zellen, Erythrocyten-Verteilungsbreite, Thrombocyten-Verteilungsbreite, mittleres Thrombocytenvolumen, Thrombocyten-Volumenanteil am Gesamtblut. Untersucht wurden auch äußere Einflüsse wie Geschlechtsunterschiede, Rauchen, Einnahme oraler Antikonzeptiva usw. Die Anwendung der kritischen Differenzen gemeinsam mit hämatölogischen Daten scheint dẹn Wert dieser Kenngrößen in Diagnose und Behandlung der Patienten żu verbessern.

\section{Introduction}

In the past the quantitation of haematologic parameters has been rather difficult because of the imprecision of the analytical procedures, which relied mainly on manual eye counting.
The recent introduction of a new precise automated haematology analyser (H-6000, Technicon Instruments Corporation, Tarrytown), combining the quantitation of the complete blood cell count with the determination of the differential leukocyte count, 
has now decreased the analytical variation. There has been an especial improvement in the precision of the differential count, mainly due to the fact that the analyser screens about 10000 leukocytes in each analysis (1-4).

Moreover, the new haematology analyser has made it possible to determine a series of other partly new parameters in the haematological field. The leukocytes are classified according to size and peroxidase activity, except for the basophils. The basophils are separated from the rest of the cells on the basis of their colorimetric reaction with the heparin.

Improvements in the technical precision of the cell count analysis do not remove biological inter-individual variability. The problem of interpretation of haematological data, where a great variability is possible within the so-called "normal" referencerange, is still present. Amongst other factors this is due to inter-individual differences in cell kinetics, depending on a large number of circumstances such as sex, age, stress, nutritional factors and many others. Often longitudinal variations of parameters withinone-patient might indicate pathology although the actual data obtained are still within the reference range.

In this investigation we studied both short-term within-one-day physiological intra-individual variation and also variations from day to day during a one-week period. Long-term intra-individual variation was studied by taking blood samples monthly from a group of 274 individuals, always at the same time of the month.

Long-term variation exists for components of both biological and analytical origin. For the interpretation of a patient's data, the behaviour of these variable components should be known in order to detect pathological variation, i.e. variation within a certain period exceeding the usual biological and analytical variations. Using the biological and the analytical variation, the so-called critical differences can be calculated $(5,6)$. The importance of the critical difference is to indicate the range which covers the great majority $(95 \%)$ of the differences between two obtained values of one laboratory parameter in one healthy individual (7). When the observed differences exceed the critical difference we consider the former ones as being of clinical importance.

In the present study the complete blood cell count, the differential count and some new parameters (large unstained cells, high peroxidase cells, red cell distribution width, platelet distribution width, mean platelet volume, plateletcrit), have been investigated.
This is certainly of great interest and even more so because by using the haematological analyser (differentiating 10000 leukocytes in every analysis) the technical precision of the analysis is greatly improved. Previously, it was hardly possible to detect slight biological variations or trends in patient's material, on account of gross techńical imprecision of the manual differential counting procedures.

Another reason for performing the underlying study was that new parameters, as mentioned above, have until now not been studied with regard to their usefulness in longitudinal treatment control of patients and development of disease. Moreover, the usefulness of any parameters can now be estimated by taking the critical difference into account.

\section{Material and Methods}

\section{Individuals}

Three groups of healthy volunteers are included in our studies. A group of 62 persons were admitted to a one-day study. A small group of 16 healthy persons were included in a one-week study for daily intra-individual longitudinal variation, whilst a large group of 274 healthy individuals were included in a six months-study.

All participants were healthy persons (age group 18-57 year) participating in the study after informed consent.

Through specified selection criteria it was possible to exclude applicants with history of disease and/or with current diseases within the last 3 months preceding the onset of the investigation. The volunteers' length, bodyweight, age and sex were registered. Smoking and the use of oral contraceptives was no reason for exclusion. All persons taking any form of medication (apart from oral contraceptives) were excluded. Further details of the participants are reported elsewhere (8).

\section{Scheme of venepuncture}

For the within-one-day period, all blood specimens from one individual were taken at fixed times i.e. 8.30 and 11.00 a.m. and 2.00 and 4.30 p.m. in the course of one day. These times were chosen because in normal pratice about $95 \%$ of blood samples for analysis are drawn within these hours.

For the day-to-day variation during six days, 16 volunteers were daily subjected to venepuncture. For the month-to-month period 274 volunteers were subjected to venepuncture monthly over a period of six months. For each volunteer the venepuncture was carried out at the same time of the day.

\section{Specimens}

The individuals had a 10 to 15 minutes rest in a sitting position before venepuncture. While the subject was in a comfortable sitting posture blood was collected in vacuum blood collection EDTA-tubes (Terumo ${ }^{\star}$ ). Brief tourniquet pressure was released immediately before venepuncture. The blood samples of all individuals at a given time were analysed in the same run.

\section{Analytical procedures}

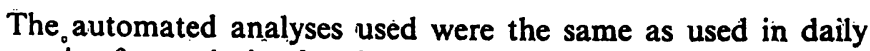
routine for analysis of patients' specimens (H-6000 ${ }^{\circ}$; Technicon Instruments Corporation, Tarrytown, N̦ew York). 


\section{Variance components}

In general three variance components can be distinguished, a biological, an analytical and an "other one" (tab. 1) (5). For the present investigation the "other" component can be neglected; specimen collection is usually its main part and to minimise this component, in this study the collection is standardised by using a vacuum collecting system.

Tab. 1. Symbols of the variance components used in this study (5)

$s_{T}^{2}=$ total variance of one individual from a reference population

$s_{\mathbf{T}}^{2}=s_{B}^{2}+s_{A}^{2}+s_{O}^{2}$

$$
s_{\mathrm{B}}^{2}=\text { biological variance }
$$

$$
\begin{array}{ll}
s_{\mathrm{B}}^{2}=\mathrm{s}_{\mathrm{P}}^{2}+\mathrm{s}_{\mathrm{T}}^{2} & \mathrm{~s}_{\mathrm{P}}^{2}=\text { intra individual variance } \\
& s_{1}^{2}=\text { inter-individual variance } \\
& \mathrm{s}_{\mathrm{1}}^{2}=\text { absent in this study }
\end{array}
$$

$s_{A}^{2}=s_{S}^{2}+s_{L}^{2} \quad s_{S}^{2}=$ variance within the run $s_{L}^{2}=$ variable between runs $s_{L}^{2}=$ absent in this study

$s_{0}^{2}=$ "Other" variance, e.g. specimen collection

Corresponding coefficients of variation (percentages) are denoted by $\mathrm{CV}_{\mathrm{T}}, \mathrm{CV}_{\mathrm{B}}$ and $\mathrm{CV}_{\mathrm{A}}$.

$\mathrm{d}_{\mathrm{K}}=$ critical difference

$d_{k}=2 \sqrt{2 s_{T}^{2}}=2 \sqrt{2\left(s_{\mathrm{P}}^{2}+s_{S}^{2}\right)}$

or

$d_{K}=2 \sqrt{2 C V_{T}^{2}}=2 \sqrt{2\left(C V_{P}^{2}+C V_{S}^{2}\right)}$

For each individual total individual variances $\left(\mathrm{s}_{\mathrm{T}}^{2}\right)$ can be calculated from the observations. Assuming the analytical component to be known, the biological one can be computed from:

$$
s_{\mathrm{B}}^{2}=\mathrm{s}_{\mathrm{T}}^{2}-\mathrm{s}_{\mathrm{A}}^{2}
$$

In this study we only consider the intra-individual variation. According to the terminology of table $1 s_{B}=s_{P}$ and $s_{A}=s_{L}$. The reported results are mainly given in coefficients of variation.

The characterize the variability of $\mathrm{CV}_{\mathrm{p}}$ for each parameter, three characteristics of the histograms of $62,16,274 \mathrm{CV}_{\mathrm{p}}$ values will be reported:

- the percentage of individuals with $\mathbf{C V}_{\mathrm{T}}>\mathrm{CV}_{\mathrm{S}}$ (denoted by $\mathbf{n}_{\text {var. }}$ )

- the median value, denoted by $\mathrm{CV}_{\mathrm{Pso}}$

- the ninety percentile value, denoted by $C_{P 90}$

\section{Critical differences}

The critical difference $d_{k}$ has been developed as a tool to follow the course on one laboratory parameter in one individual in consecutive measurements. The critical difference is dependent on the total variance $s_{\mathrm{T}}^{2}$ for the one individual concerned. Because in our study the critical difference is predominantly dependent on the intra-individual variance $s_{p}^{2}$ and the inter-run variance $s_{L}^{2}$, it can be written as:

$$
\text { or } \begin{aligned}
d_{k} & =2 \sqrt{2 s_{T}^{2}}=2 \sqrt{2\left(s_{P}^{2}+s_{L}^{2}\right)} \\
d_{K} & =2 \sqrt{2\left(C V_{P}^{2}+C V_{L}^{2}\right)} \quad \text { (in units) }
\end{aligned}
$$

\section{Statistical methods}

Each parameter in this study was investigated with the Friedman rank test (9) to determine whether a systematic pattern could be found. Such a pattern could be either an upward or a downward trend or a systematic low or high value at one particular point.

Several two-group comparisons (like male versus female, smokers/non smokers) were performed using the Mann-Whitney test (10). Correlations were studied using the Spearman rank correlation test (10).

\section{Results}

\section{Analytical variation}

The analytical within-run variations of the different haematological analyses are presented in terms of coefficient of variation (tab. 2). The long-term analytical variations are given in table 3 . It appears that of the sixteen haematological parameters, eight show a coefficient of variation below $5 \%$, whereas another six show a coefficient of variation between $5 \%$ and $10 \%$. Two parameters, large unstained cells and high peroxidase cells, have coefficients of variation greater than $10 \%$ within the run. For the long-term precision eight parameters show a precision (coefficient of variation) below $5 \%$ and five parameters have a coefficient of variation between $5 \%$ and $10 \%$. Three parameters, basophils, large unstained cells and high peroxidase cells have coefficients of variation over $10 \%$. The latter fact may be due to the rare occurence of these cells leading to small numbers in the analysis. It is noted that there is a rather good agreement between the within-run coefficients of variation and the coefficients of variation in long-term, of course the latter being slightly higher.

Influences due to storage were avoided by analysing the samples as soon as possible after blood sampling.

\section{Short-term variation}

\section{Within-one-day variation}

When the Friedman rank test was applied to the patient's haematology results in the one-day study, no systematic low or high value at one single time point was found. However, we observed a significant $(p<0.05)$ upward trend in the course of the day for the platelet count, mean platelet volume, plateletcrit, the leukocyte count and the percentage of high peroxidase cells (tab. 4). No downward trends over the day were seen.

The observed changes possibly can be a result of the increasing physiologic stress in the course of the day.

This stress causes an increase in the rate of production of platelets and leukocytes by the bone marrow. The increase can be accounted for by younger cells; in the case of platelets, these are distinguishable from the 
Tab. 2. Intra-individual variation and the critical difference during one day $(n=62)$

\begin{tabular}{|c|c|c|c|c|c|c|}
\hline Parameters & $\begin{array}{l}\mathrm{n}_{\mathrm{var}} \\
\%\end{array}$ & $\begin{array}{l}\mathrm{CV}_{\mathrm{s}} \\
\%\end{array}$ & $\begin{array}{l}\mathrm{CV}_{\mathrm{P} 50} \\
\%\end{array}$ & $\begin{array}{l}d_{K s 0} \\
\%\end{array}$ & $\begin{array}{l}\mathrm{CV}_{\mathrm{P} 90} \\
\%\end{array}$ & $\begin{array}{l}d_{K 90} \\
\%\end{array}$ \\
\hline $\begin{array}{l}\text { Erythrocytic parameters } \\
\text { Erythrocytes } \\
\text { Haemoglobin } \\
\text { Haematocrit } \\
\text { Red cell distribution width }\end{array}$ & $\begin{array}{l}52 \\
58 \\
45 \\
47\end{array}$ & $\begin{array}{l}2.7 \\
2.6 \\
2.9 \\
1.5\end{array}$ & $\begin{array}{l}0.6 \\
1.1 \\
0.0 \\
0.0\end{array}$ & $\begin{array}{l}7.8 \\
8.0 \\
8.2 \\
4.2\end{array}$ & $\begin{array}{ll}4.4 & \\
4.3 & . \\
4.6 & \\
1.7 & \end{array}$ & $\begin{array}{r}14.6 \\
14.2 \\
15.4 \\
6.4\end{array}$ \\
\hline $\begin{array}{l}\text { Thrombocytic parameters } \\
\text { Platelets } \\
\text { Mean platelet volume } \\
\text { Platelet distribution width } \\
\text { Plateletcrit }\end{array}$ & $\begin{array}{l}38 \\
32 \\
27 \\
58\end{array}$ & $\begin{array}{l}7.0 \\
3.0 \\
3.4 \\
6.0\end{array}$ & $\begin{array}{l}0.0 \\
0.0 \\
0.0 \\
2.7\end{array}$ & $\begin{array}{r}19.8 \\
8.5 \\
9.6 \\
18.6\end{array}$ & $\begin{array}{r}6.7 \\
3.8 \\
3.8 \\
13.2\end{array}$ & $\begin{array}{l}27.4 \\
13.7 \\
14.4 \\
41.0\end{array}$ \\
\hline $\begin{array}{l}\text { Leukocyte and differential count } \\
\text { Total leukocytes } \\
\text { Neutrophils } \\
\text { Lymphocytes } \\
\text { Monocytes } \\
\text { Eosinophils } \\
\text { Basophils } \\
\text { Large unstained cells } \\
\text { High peroxidase cells }\end{array}$ & $\begin{array}{r}75 \\
98 \\
100 \\
88 \\
88 \\
88 \\
80 \\
55\end{array}$ & $\begin{array}{r}7.0 \\
1.4 \\
1.8 \\
6.6 \\
7.5 \\
9.7 \\
13.6 \\
23.2\end{array}$ & $\begin{array}{r}9.5 \\
6.5 \\
10.0 \\
11.3 \\
16.3 \\
19.4 \\
14.5 \\
12.4\end{array}$ & $\begin{array}{l}33.4 \\
18.8 \\
28.7 \\
37.0 \\
50.7 \\
61.3 \\
56.2 \\
74.4\end{array}$ & $\begin{array}{l}19.9 \\
15.1 \\
23.6 \\
24.8 \\
28.8 \\
41.3 \\
32.7 \\
46.3\end{array}$ & $\begin{array}{r}59.7 \\
42.9 \\
66.9 \\
72.6 \\
84.2 \\
120.0 \\
100.2 \\
146.5\end{array}$ \\
\hline
\end{tabular}

$\mathrm{n}_{\mathrm{var}} \quad=$ percentage of individuals in the group with $\mathrm{CV}_{\mathrm{T}}>\mathrm{CV}_{\mathrm{S}}$

$\mathrm{CV}_{\mathrm{P} 50}=$ median of intra-individual coefficient of variation

$\mathrm{CV}_{\mathrm{P} 90}=90$ percentile of intra-individual coefficient of variation

$\mathrm{d}_{\mathrm{K} 50}=$ critical difference based on $\mathrm{CV}_{\mathrm{P} 50}$

$\mathrm{d}_{\mathrm{K} 90}=$ critical difference based on $\mathrm{CV}_{\mathrm{P} 90}$

$\mathrm{CV}_{\mathrm{T}}=$ total coefficient of variation of one individual from a reference population

$\mathrm{CV}_{\mathrm{S}}=$ intra-run coefficient of analytical variation

Tab. 3. Intra-individual variation and the critical difference during six months $(n=274)$

\begin{tabular}{|c|c|c|c|c|c|c|}
\hline Analytical parameters & $\begin{array}{l}\dot{\mathrm{n}}_{\mathrm{var}} \\
\%\end{array}$ & $\begin{array}{l}\mathrm{CV}_{\mathrm{L}} \\
\%\end{array}$ & $\begin{array}{l}C V_{\text {Pso }} \\
\%\end{array}$ & $\begin{array}{l}\mathrm{d}_{\mathrm{K} 50} \\
\%\end{array}$ & $\underset{\%}{C V_{P 90}}$ & $\begin{array}{l}d_{\mathrm{K} 90} \\
\%\end{array}$ \\
\hline \multicolumn{7}{|l|}{ Erythrocytic parameters } \\
\hline Erythrocytes & 57 & 3.8 & 1.4 & 11.5 & 5.0 & 17.8 \\
\hline Haemoglobin & 41 & 3.6 & 0.0 & 10.2 & 4.2 & 15.6 \\
\hline Haematocrit & 34 & 3.7 & 0.0 & 10.5 & 3.4 & 14.2 \\
\hline Red cell distribution width & 97 & 2.1 & 3.7 & 12.0 & 5.3 & 16.1 \\
\hline \multicolumn{7}{|l|}{ Thrombocytic parameters } \\
\hline Platelets & 49 & 8.1 & 0.0 & 22.9 & 10.6 & 37.7 \\
\hline Mean platelet volume & 89 & 3.8 & 4.3 & 16.2 & 8.0 & 25.1 \\
\hline Platelet distribution width & 73 & 4.0 & 3.2 & 14.5 & 6.3 & 21.1 \\
\hline Plateletcrit & 95 & 6.9 & 11.6 & 38.2 & 20.6 & 61.4 \\
\hline \multicolumn{7}{|c|}{ Leukocyte and differential count } \\
\hline Total leukocytes & 86 & 7.9 & 8.9 & 33.7 & 17.3 & 53.8 \\
\hline Neutrophils & 98 & 2.0 & 6.3 & 18.7 & 12.5 & 35.8 \\
\hline Lymphocytes & 100 & 2.3 & 10.8 & 31.2 & 21.3 & 60.6 \\
\hline Monocytes & 97 & 7.8 & 16.4 & 51.4 & 30.7 & $89: 6$ \\
\hline Eosinophils & 97 & 8.6 & 20.8 & 63.7 & 41.3 & 119.3 \\
\hline Basophils & 96 & 11.3 & 32.0 & 96.0 & 56.9 & 164.1 \\
\hline Large unstained cells & 94 & 15.4 & 25.9 & 85.2 & 42.7 & 128.4 \\
\hline High peroxidase cells & 74 & 28.1 & 22.9 & 102.5 & 49.1 & 160.0 \\
\hline
\end{tabular}

$\mathrm{n}_{\mathrm{var}}=$ percentage of individuals in the group in whom $\mathrm{CV}_{\mathbf{T}}>\mathrm{CV}_{\mathrm{L}}$

$\mathrm{CV}_{\mathrm{PSO}}=$ median of intra-individual coefficient of variation

$\mathrm{CV}_{\mathrm{P} 90}=90$ percentile of intra-individual coefficient of variation

$\mathrm{d}_{\mathrm{K} \text { so }}=$ critical difference based on $\mathrm{CV}_{\mathrm{P} \text { so }}$

$\mathrm{d}_{\mathrm{K} 90}=$ critical difference based on $C V_{\mathrm{P} 90}$

$\mathrm{CV}_{\mathrm{T}}=$ total coefficient of variation of one individual from a reference population

$\mathrm{CV}_{\mathbf{L}}=$ day-to-day coefficient of analytical variation 
Tab. 4. Results of the Friedman rank test for the blood cell parameters, in which a significant trend over the four venepuncture times was found

\begin{tabular}{llllll}
\hline Parameter & Mean values & & & p-values \\
\hline Mean Ranks & 8.30 a.m. & 11.00 a.m. & 2.00 p.m. & 4.30 p. m. \\
\hline Platelets & 2.08 & 2.13 & 2.78 & 3.06 & 0.001 \\
Mean platelet volume & 2.17 & 2.32 & 2.52 & 2.98 & 0.004 \\
Plateletcrit & 2.07 & 2.12 & 2.78 & 3.06 & 0.001 \\
Total leukocytes & 1.72 & 2.35 & 2.57 & 3.36 & 0.001 \\
High peroxidase cells & 1.93 & 2.32 & 2.85 & 2.90 & 0.001 \\
\hline
\end{tabular}

"older" ones by their volume (mean platelet volume and the platelet "crit" increase), whereas the younger leukocytes contain a higher peroxidase activity.

Intra-individual variations have been calculated from the data obtained from within-one-day samples. There are two possibilities, either $\mathrm{CV}_{\mathrm{T}}>\mathrm{CV}_{\mathrm{S}}$, in which case $\mathrm{CV}_{\mathrm{P}}$ is found positive, or $\mathrm{CV}_{\mathrm{T}} \leqq \mathrm{CV}_{\mathrm{S}}$ in which case $\mathrm{CV}_{\mathrm{P}}$ cannot be calculated and is considered to be equal to zero. The first situation has been observed only in a minority of the parameters. For 6 of the 16 parameters more than $85 \%$ of the participating individuals show a positive $\mathrm{CV}_{\mathrm{P}}$. The results are summarized in table 2.

As shown in table 2 the intra-individual variations varied from $0.0 \%$ to $19.4 \%\left(\mathrm{CV}_{\mathrm{P} 50}\right)$ and from $1.7 \%$ to $46.3 \%\left(\mathrm{CV}_{\mathrm{P} 90}\right)$. The critical differences were from $4.2 \%$ to $74.4 \%\left(\mathrm{~d}_{\mathrm{K} 50}\right)$ and from $6.4 \%$ to $146.5 \%\left(\mathrm{~d}_{\mathrm{K} 90}\right)$.

Using the Mann Whitney test we have investigated for which parameters significant differences were present between males and females, between male smokers and non-smokers, between female smokers and non-smokers and between females with and without oral contraceptives. For the differences between males and females only the lymphocyte count seems to be of relevance.

In the male smokers/non smokers group there is a difference for the platelet distribution width and the mean platelet volume. The intra-individual variations of female smokers and non-smokers only differed in the leukocyte count. Although the differences are significant from a statistical point of view, they seem to be of no importance in clinical use. Examining scatter-diagrams and coefficients of correlation, we found no correlations between intra-individual variation and age, length, bodyweight and levels of corresponding laboratory parameters. All but the leukocyte, lymphocyte and monocyte within-one-day intra-individual variations are lower than or equal to the month-to-month intra-individual variation (tab. 2 , $3)$. It can thus be concluded that the majority of the within-one-day intra-individual variations of hae- matological parameters are smaller than or similar to the month-to-month intra-individual variation.

Critical differences $\left(d_{K ~ s 0}\right.$ and $\left.d_{K 90}\right)$ for both males and females expressed in absolute values (SI units) are given in table 5 .

\section{Day-to-day variation}

In order to bridge the gap between really short-term (within-one-day) and long-term variance data, we decided to study the short-term day-to-day variation of parameters in 16 healthy individuals. From table 6 it appears that although there are some differences between the variability within-one-day and the other periods, the variability of parameters from day-today during one week and from month-to-month during a six months period are remarkably similar. Therefore, we think it is justified to concentrate our attention to the larger group of 274 individuals who were studied during a six-months-period.

\section{Long-term variation}

\section{Month-to-month variation}

Using the Friedman rank test, we investigated the prevalence of any systematic low or high values or upward or downward trends over a six months period. In our data no such systematic phenomena were found. The variability of the haematological parameters is expressed as $n_{v a r}$, i.e. the percentage of individuals in the group wherein $C_{T}>C V_{L}$.

In table 3 are given the calculated results for $\mathrm{CV}_{\mathrm{P} \text { s0 }}, \mathrm{CV}_{\mathrm{P} 90}, \mathrm{~d}_{\mathrm{K} \text { s0 }}$ and $\mathrm{d}_{\mathrm{K} 90}$. As can be seen, the month-to-month intra-individual variations $C_{P 50}$ and $\mathrm{CV}_{\mathrm{P} 90}$ from most of the haematological parameters were greater than zero except for the $C_{P} V_{P 0}$ of haemoglobin, haematocrit and plateletcount.

The month-to-month intra-individual variations variedfrom $0.0 \%-32.0 \%\left(C_{\mathrm{P} \mathrm{s0}}\right)$ andfrom $3.4-56.9 \%$ $\left(\mathrm{CV}_{\mathrm{P} 90}\right)$. The critical differences varied from $10.2-102.5 \%\left(d_{K ~ s 0}\right)$ and from $14.2-164.1 \%\left(d_{k 90}\right)$. 
Tab. 5. The critical difference observed during one day based on $s_{L}$

\begin{tabular}{|c|c|c|c|c|c|c|c|c|c|}
\hline \multirow[t]{2}{*}{ Parameter } & \multirow{2}{*}{$\begin{array}{l}\text { Dimen- } \\
\text { sion }\end{array}$} & \multicolumn{2}{|c|}{ Mean values } & \multicolumn{2}{|l|}{$d_{K 50}$} & \multicolumn{2}{|l|}{$d_{K 90}$} & \multicolumn{2}{|c|}{$\begin{array}{l}\text { Transverse } \\
\text { reference values }\end{array}$} \\
\hline & & male & female & male & female & male & female & male & female \\
\hline $\begin{array}{l}\text { Erythrocytic parameters } \\
\text { Erythrocytes } \\
\text { Haemoglobin } \\
\text { Haemotocrit } \\
\text { Red cell distribution width }\end{array}$ & $\begin{array}{l}10^{12} / 1 \\
\mathrm{mmol} / 1\end{array}$ & $\begin{array}{l}4.88 \\
9.4 \\
0.45 \\
14.6\end{array}$ & $\begin{array}{c}4.55 \\
8.6 \\
0.43 \\
14.6\end{array}$ & $\begin{array}{l}0.53 \\
1.0 \\
0.05 \\
0.9\end{array}$ & $\begin{array}{l}0.50 \\
0.9 \\
0.05 \\
0.9\end{array}$ & $\begin{array}{l}0.80 \\
1.5 \\
0.08 \\
1.1\end{array}$ & $\begin{array}{l}0.75 \\
1.4 \\
0.07 \\
1.1\end{array}$ & $\begin{array}{r}4.2-15.6 \\
8.5-11.0 \\
0.41-0.51 \\
14.3-17.6\end{array}$ & $\begin{array}{c}3.7-5.0 \\
7.5-10.0 \\
0.36-0.47 \\
14.3-17.6\end{array}$ \\
\hline $\begin{array}{l}\text { Thrombocytic parameters } \\
\text { Platelets } \\
\text { Mean platelet volume } \\
\text { Platelet distribution width } \\
\text { Plateletcrit }\end{array}$ & $\begin{array}{l}10^{9} / 1 \\
\text { fl } \\
\%\end{array}$ & $\begin{array}{c}236 \\
9.8 \\
38.4 \\
0.25\end{array}$ & $\begin{array}{c}257 \\
9.8 \\
38.4 \\
0.25\end{array}$ & $\begin{array}{l}54 \\
1.1 \\
4.4 \\
0.05\end{array}$ & $\begin{array}{l}59 \\
1.1 \\
4.4 \\
0.05\end{array}$ & $\begin{array}{l}70 \\
1.5 \\
6.0 \\
0.11\end{array}$ & $\begin{array}{l}76 \\
1.5 \\
6.0 \\
0.11\end{array}$ & $\begin{array}{c}171-303 \\
8.0-0.9 \\
33.8-42.1 \\
0.15-0.35\end{array}$ & $\begin{array}{c}194-358 \\
8.0-9.9 \\
33.8-42.1 \\
0.15-0.35\end{array}$ \\
\hline $\begin{array}{l}\text { Leukocyte and differential count } \\
\text { Total leukocytes } \\
\text { Neutrophils } \\
\text { Lymphocytes } \\
\text { Monocytes } \\
\text { Eosinophils } \\
\text { Basophils } \\
\text { Large unstained cells } \\
\text { High peroxidase cells }\end{array}$ & $\begin{array}{l}10^{9} / 1 \\
\% \\
\% \\
\% \\
\% \\
\% \\
\% \\
\%\end{array}$ & $\begin{array}{c}6.8 \\
59 \\
31 \\
4.8 \\
3.0 \\
0.9 \\
0.9 \\
0.6\end{array}$ & $\begin{array}{c}6.8 \\
59 \\
31 \\
4.8 \\
3.0 \\
0.9 \\
0.9 \\
0.6\end{array}$ & $\begin{array}{l}2.4 \\
11 \\
9 \\
1.9 \\
1.6 \\
0.6 \\
0.5 \\
0.5\end{array}$ & $\begin{array}{c}2.4 \\
11 \\
9 \\
1.9 \\
1.6 \\
0.6 \\
0.5 \\
0.5\end{array}$ & $\begin{array}{c}4.1 \\
25 \\
21 \\
3.5 \\
2.6 \\
1.1 \\
0.9 \\
0.9\end{array}$ & $\begin{array}{l}4.1 \\
25 \\
21 \\
3.5 \\
2.6 \\
1.1 \\
0.9 \\
0.9\end{array}$ & $\begin{aligned} 5-10 \\
40-75 \\
15-50 \\
2-8 \\
0-5 \\
0-2 \\
<2.2 \\
<2.5\end{aligned}$ & $\begin{array}{c}5-10 \\
40-75 \\
15-50 \\
2-8 \\
0-5 \\
0-2 \\
<2.2 \\
<2.5\end{array}$ \\
\hline
\end{tabular}

mean values are taken over all time points and all individuals

Tab. 6. Coefficients of intra-individual variation of haematological parameters

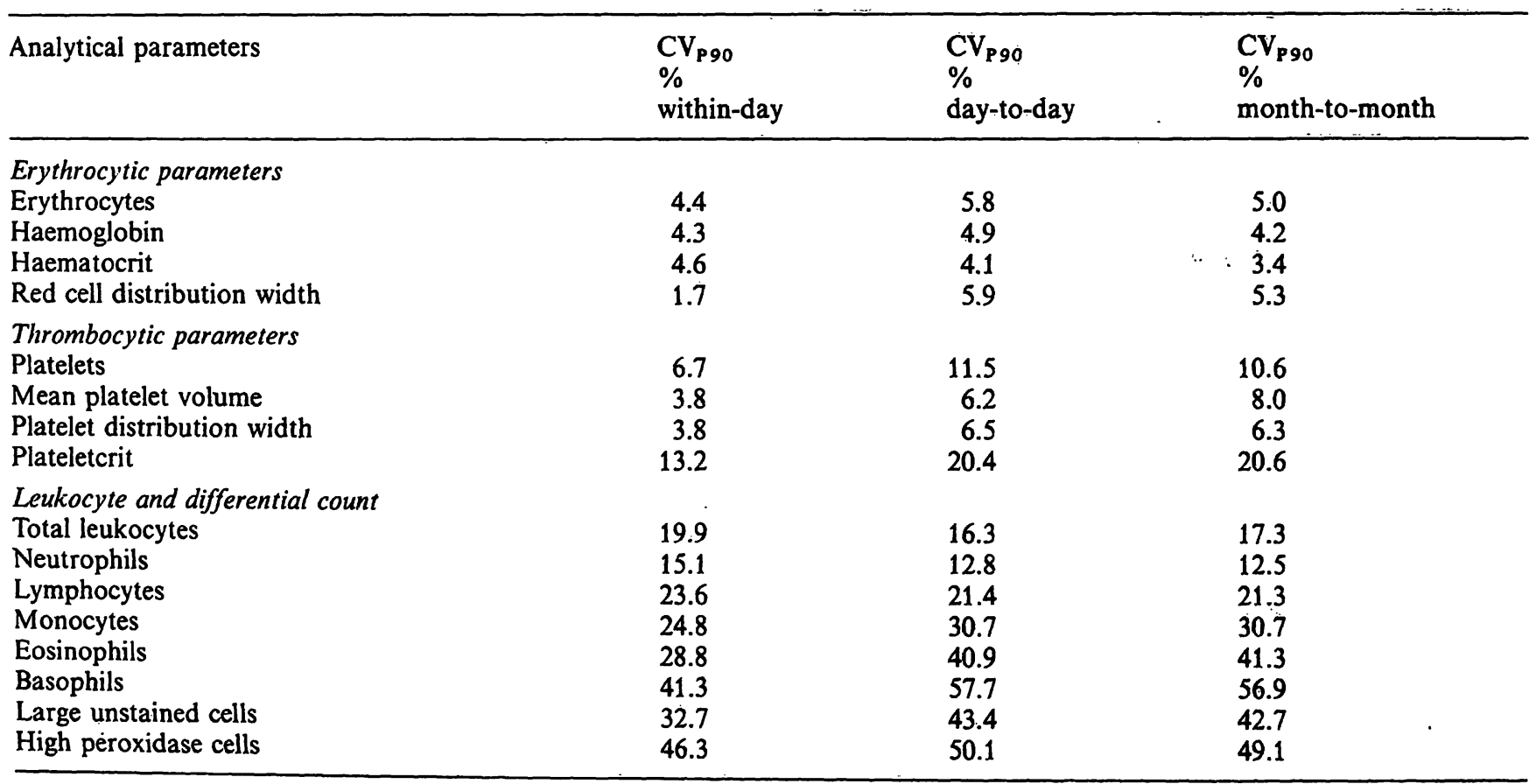

Using the Mann Whitney test we tested the existence of a significant difference in the intra-individual variation between males and females. Such differences were found for haemoglobin, red cell distribution width, platelet distribution width, basophils and large unstained cells. Male smokers and non-smokers differed with respect to high peroxidase cells, whereas female smokers and non-smokers showed no difference in this parameter. Differences for neutrophils and monocytes have been observed between females 
taking/not-taking oral contraceptives. Although the reported differences are statistically significant $(P<0.05)$, the clinical importance of this observation is unclear.

Examination of scatter diagrams and coefficients of correlation revealed no correlations between intraindividual variation and age, height, body-weight and levels of corresponding laboratory parameters.

The critical differences ( $\mathrm{d}_{\mathrm{K} 50}$ and $\mathrm{d}_{\mathrm{K} 90}$ ) based on $\mathrm{SL}$ for both males and females expressed in absolute values (SI units) are summarized in table 7.

\section{Discussion}

While studying the literature on the intra-individual variability of haematological data, our attention was drawn to two papers by Statland et al. $(3,4)$. Comparison of our results with data from the literature (tab.8) could not be made for the critical differences, as these have not been reported before in this field. The investigations of Statland et al. were based on relatively small groups ( 20 and 38 subjects), which do not permit sound statistical evaluation. For the same reason no attention could be paid to differences within

Tab. 7. Critical differences observed during six months for males and females basend on sL.

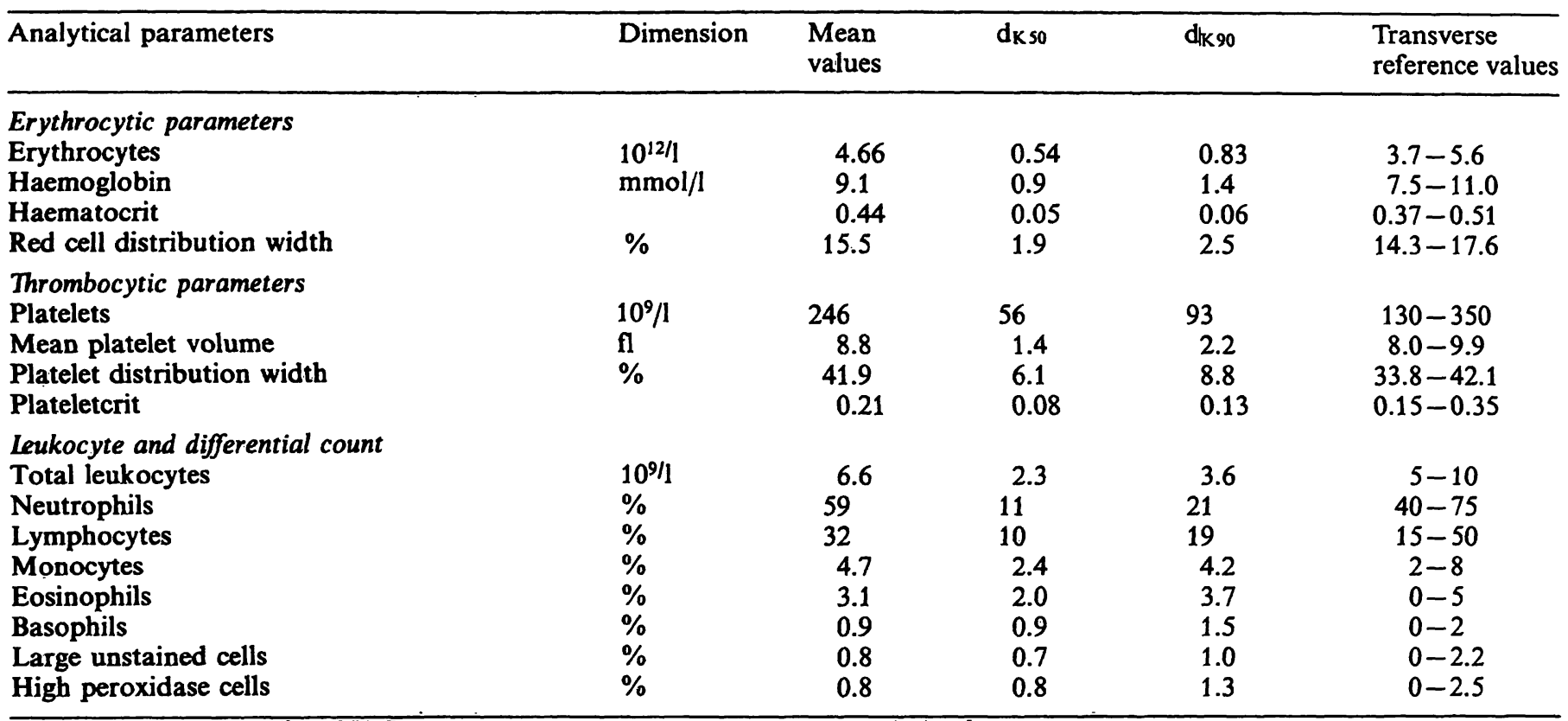

mean value are taken over all months and all individuals

Tab. 8. Intra-individual variation from the literature

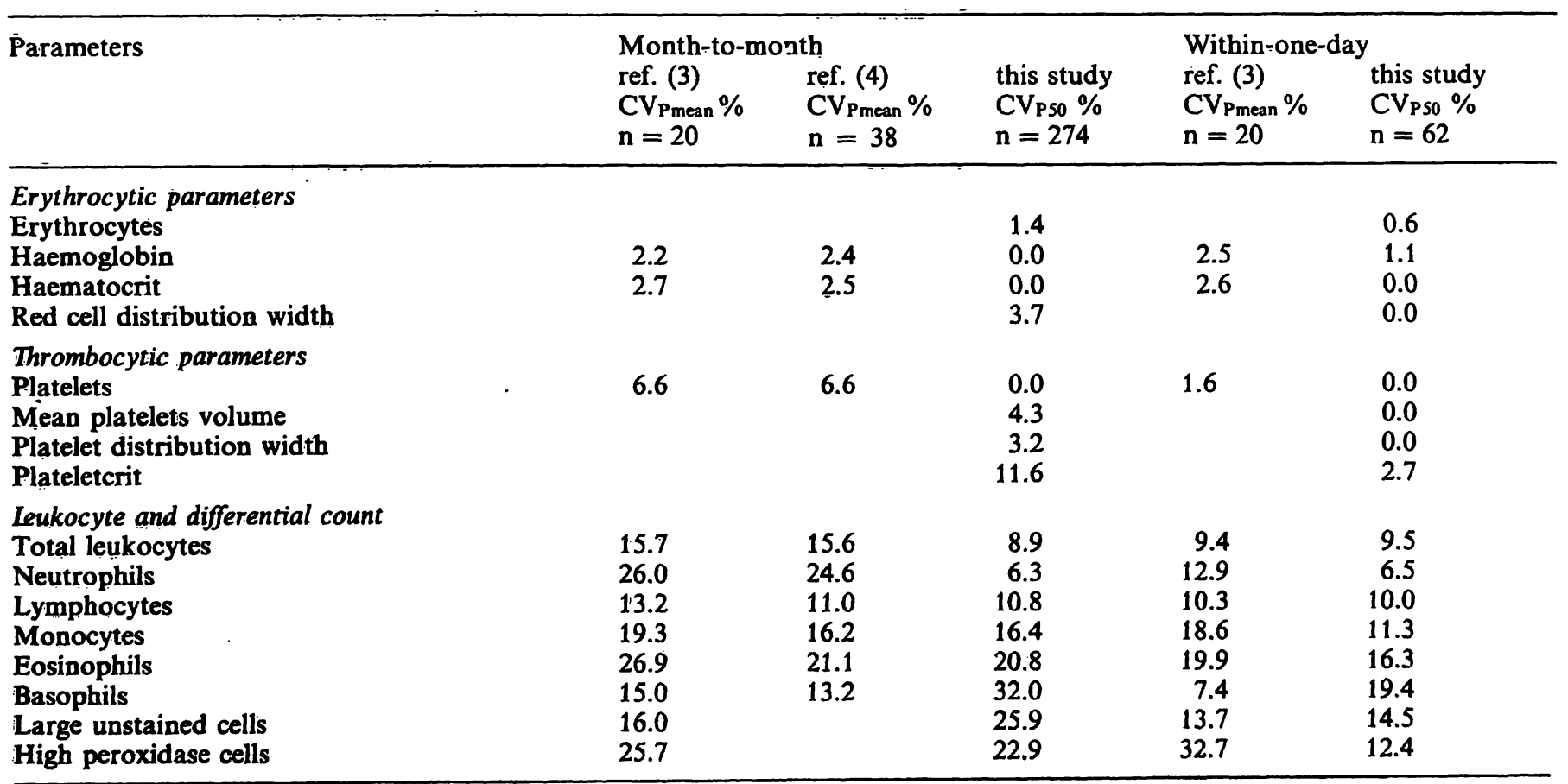


groups such as males/females, smokers/non-smokers, influence of age, bodyweight, height and taking/nottaking oral contraceptives. Moreover, the biological variability of reference population and target population are to a large extent incomparable, because the groups consisted only of employees of of the clinical laboratory in the age range 25 to 46 years. Furthermore, Statland et al. calculated the mean physiological hour-to-hour (with-in-one-day) and week-toweek (month-to-month) intra-individual variations in terms of coefficients of variation. In our opinion it is better to consider the 50 percentile of the physiological hour-to-hour (within-one-day) and week-to-week (month-to-month) intra-individual variance data because the parameter distributions are not Gaussian.

Some interesting features resulting from our study should be mentioned.

First, the interest of $d_{K 90}$ values appears to be twofold. A large $d_{K 90}$ range for any parameter means that variability in one patient's values must be considerable to be of clinical importance. This of course is a restriction in the usefulness of such a parameter. It can even be questioned whether parameters where $d_{K 90}$ values of over e. g. $150 \%$ are found, are of any interest to the clinician or that these parameters should remain on the laboratory list at all. This is especially true when consecutive patient's data are considered. However, such parameters can still be useful in the so-called transverse reference range for the detection of evident pathology. Another interesting observation is that the $C_{P 90}$ values for parameters of differentiated cell types seem to be inversely correlated to the life span of these cells. Lower values of $\mathrm{CV}_{\mathrm{P} 90}$ are found for parameters of the red blood cells with a life-span of about 120 days. Elevated values of $\mathrm{CV}_{\mathbf{P} 90}$ are found for the parameters of the white blood cells that have been present in the circulation for only 6 to 8 hours. Finally, intermediate values for $\mathrm{CV}_{\mathbf{P} 90}$ were found for parameters of platelets, the latter having a lifespan of about 10 days in the blood.

$\mathrm{CV}_{\mathrm{P} 90}$ values are an expression of the degree of interindividual scatter, and the time for which a cell type endures in the circulation indicates its turnover rate. The hypothesis that a low intra-individual scatter degree is combined with a low turnover rate of any type of blood cells seems acceptable and is confirmed by our above-mentioned findings.

Finally, attention is drawn to the observation that the differences in $\mathbf{C V}_{\mathbf{P} 90}$ values in the day-to-day compared to the month-to-month study are rather small. The data for these periods are in general larger than in the within-one-day-study. This tendency for increase was noted in most parameters excluding haematocrit, total leukocyte counts and the differential counts for neutrophils and lymphocytes. This could perhaps partly be explained by the short turnover time of leukocytes in the blood and by possible homeostatic changes in the course of the day. It seems advisable to draw blood at least for the determination of these parameters at a fixed time of the day and to be aware of these facts in the clinical interpretation of laboratory data.

It can be concluded that the use of data on intraindividual variability and the critical differences facilitates decisions on diagnosis and treatment of disease as far as haematological laboratory data are concerned. Moreover, possibly unphysiological or even pathological changes within the generally used transverse reference ranges can be detected. This certainly is important for the early detection of development of disease.

\section{References}

1. Winkel P., Statland B. E., Saunders A. M., Osborn H. \& Kupperman H. (1981) Am. J. Clin. Pathol. 75, 693-700.

2. Mansberg H. P., Saunders A. M. \& Groner W. (1974) J. Histochem. Cytochem. 22, 711-724.

3. Statland B. E., Winkel P., Harris S. C., Burdsall M. J. \& Saunders A. M. (1978) Am. J. Clin. Pathol. 69, 48-54.

4. Statland B. E. \& Winkel P. (1977) CRC. Crit. Rev. Clin. Lab. Sci. $10,105-144$.

5. Stamm D. (1981) Control of Analytical Variation in the Production of Reference Values. In: Reference Values in Laboratory Medicine (Gräsbeck R. \& Älström T., eds.) New York, John Wiley \& Sons, pp. 109-126.

6. Young D. S. (1978) Clin. Chem. 24, 212-222.

7. Rümke C. C., Bezemer P. D. \& Kuik D. J. (1975) J. Chron. Dis. $28,661-668$.

8. Costongs G. M. P. J., Janson P. C. W., Bas B. M., Hermans J., van Wersch J. W. J. \& Brombacher P. J. (1985) J. Clin. Chem. Clin. Biochem. 23, 7-16.

9. Friedman M. (1937) J. Am. Statist. Assoc. 32, 675-701.

10. Armitage P. (1971) Statistical Methods in Medical Research, Blackwell, Oxford.

Dr. med. G. M. P. J. Costongs

Department of Clinical Chemistry

"Ziekenhuis De Goddelijke Voorżienigheid"

Walramstraat 23

NL-6131 BK Sittard :; 